\title{
Thyroid gland function and growth in IGF binding protein-1 transgenic mice
}

\author{
Tomislav Modric ${ }^{1}$, Kadaba Rajkumar ${ }^{1}$ and Liam J Murphy ${ }^{1,2}$ \\ Departments of ${ }^{1}$ Physiology and ${ }^{2}$ Internal Medicine, University of Manitoba, Winnipeg, Manitoba, Canada R3E OW3 \\ (Correspondence should be addressed to L J Murphy, 730 William Avenue, Winnipeg, Manitoba, Canada R3E 3J7)
}

\begin{abstract}
Objective: IGF-I, IGF-I receptor and IGF-binding proteins (IGFBPs) are expressed in thyroid tissue and are associated with the function and growth of the thyroid. This study investigated the in vivo and in vitro effects of increased IGFBP-1 levels on the function and growth of the thyroid gland.

Design: Transgenic mice which constitutively overexpress IGFBP-1 were used. These mice have a phenotype consistent with partial inhibition of IGF-I action.

Methods: Thyroid growth, morphology and hormonogenesis were determined in transgenic mice treated with goitrogens, sodium perchlorate and methimazole. In vitro cell proliferation in thyroid follicles was assessed in response to IGF-I and TSH.

Results: Thyroid weight was increased in transgenic mice, relative to their body mass, whereas serum tri-iodothyronine $\left(\mathrm{T}_{3}\right)$, thyroxine and $\mathrm{T}_{3}$-binding capacity were reduced, compared with wildtype. While an inverse relationship between $\mathrm{T}_{3}$ and TSH was observed in both groups of goitrogentreated mice, the slope of the line of best fit was less steep in transgenic mice compared with wild-type mice. Thyroid growth was less marked in transgenic than wild-type mice in response to goitrogens, although TSH levels were higher in goitrogen-treated transgenics. In vitro proliferative response of isolated thyroid follicles to IGF-I, but not to TSH, was reduced in transgenic, compared with wild-type mice.

Conclusions: The results of this study suggest that, while overexpression of IGFBP-1 attenuates IGF-I action in vitro, it enhances thyroid growth in vivo, presumably as a result of perturbations in thyroid function at multiple levels.
\end{abstract}

European Journal of Endocrinology 141 149-159

\section{Introduction}

A considerable body of evidence suggests that growth factors and cytokines, acting in an autocrine or paracrine fashion, have a role in normal thyroid growth and development, as well as in pathophysiological situations such as goiter formation and thyroid cancer. In this regard, insulin-like growth factors (IGFs), particularly IGF-I, have received considerable attention. IGF-I, the IGF-I receptor and a variety of IGF-binding proteins (IGFBPs) are expressed in thyroid tissue $(1,2)$. IGF-I facilitates thyrotropin (TSH)-induced proliferation of dog thyroid epithelium in vitro (3) and rat thyroid cell lines in culture $(4,5)$. Increased expression of IGF-I receptors has been documented in thyroid tissue from Graves' disease patients (6) and IGF-I has been implicated in the development of multinodular goiters (7). Furthermore, expression of mutant p $21^{\text {ras }}$ induces IGF-I secretion from thyroid epithelial cells (8). Since activation of $\mathrm{p} 21^{\text {ras }}$ has been found in some thyroid cancers,
IGF-I may function as an autocrine growth factor in thyroid malignancy.

The importance of the IGF system for thyroid function and growth is further supported by the observation that thyroid hormones stimulate IGFBP-1, IGF-I (9) and IGF-II (10) synthesis, indicating a possible regulatory loop involving thyroid hormones and IGFs. In addition to local expression of IGF-I in the thyroid gland, IGF-I may also be taken up from the circulation (11). The majority of circulating IGF-I is derived from the liver, with hepatic IGF-I expression and circulating levels of IGF-I and IGFBP-3 also being influenced by thyroid hormone status $(12,13)$. Since IGF-I enhances thyroid cell proliferation (14) and TSH-induced thyroid hormonogenesis (15), the possibility exists that hepatic IGF-I feeds back on the thyroid gland and that thyroid hormone status not only influences thyroidal IGF-I synthesis but also the uptake of IGF-I from the circulation.

The data discussed above provide correlative evidence that IGFs are important in thyroid gland physiology. 
Definitive experiments to test the role of the IGFs in thyroid gland physiology have not been possible in the past. Although IGF-I and IGF-I receptor knock-out mice have been generated, these animals are stillborn or die in the early post-natal period and thus are not suitable models to address the role of the IGFs in thyroid physiology (16). Recently, we have generated transgenic mice which constitutively overexpress IGFBP-1 under the phosphoglycerate kinase promoter (PGK) (17). These mice demonstrate a phenotype which is consistent with the partial inhibition of IGF action. In addition to reduced body weight and hyperglycemia, these mice also demonstrate a marked reduction in brain size. Many, but not all, growth responses are impaired in these mice. For example, estrogen-induced uterine proliferation is markedly impaired (18), whereas hepatic regeneration is not (19). Unlike the IGF-I and IGF-I receptor null mutant mice, the IGFBP-1 transgenic mice are viable and thus provide a useful model with which the effects of IGF-I blockade can be examined beyond the neonatal period. The thyroid status of these IGFBP-1 transgenic mice has not been investigated in the past. In this study, thyroid growth and function in these transgenic mice were compared with those in wild-type mice.

\section{Materials and methods}

\section{Animal experiments}

Transgenic animals used in all experiments are descendants of the $\mathrm{C} 57 \mathrm{BL} / 6 \mathrm{~J} \times \mathrm{CBA} / \mathrm{JF}_{1}$ founder $277 \mathrm{~A}$ (which have high levels of rat IGFBP-1 in their sera) and wild-type mice of the same genetic background (17). The mouse PGK promoter drives transgene expression in all tissues, especially in cells requiring high levels of glycolysis (20), which takes place in the thyroid gland (21). Two experimental designs were employed: one to compare thyroid growth and function with regard to age in transgenic and wild-type mice, and the other to compare the effects of goitrogen treatment on thyroid growth and function in the two groups of mice. Male transgenic and wild-type mice of identical genetic background were used for both experiments (17). Mice were killed between 1000 and $1200 \mathrm{~h}$. All animal experimentation was performed in accordance with protocols approved by the Animal Care Committee of the Faculty of Medicine, University of Manitoba.

\section{Thyroid function and growth with age}

At 15, 25 and 55 days of age, five transgenic and five wild-type mice were anesthetized with Avertin, weighed and exsanguinated by aspiration from the heart. Thyroid glands were dissected out under a dissecting microscope and weighed. Relative thyroid weight (RTW) was determined by expressing the thyroid weight in milligrams per $100 \mathrm{~g}$ body weight. Blood samples were left for $2-3 \mathrm{~h}$ at room temperature to coagulate and were then centrifuged. Serum was separated and frozen at $-20^{\circ} \mathrm{C}$ for $1-3$ weeks, until analyzed by RIA as described below.

\section{Goitrogen treatment}

Hypothyroidism was induced in 20 male mice (10 wild-type and 10 transgenic) at 55 days of age, by administration of $0.5 \%$ sodium perchlorate and $0.05 \%$ methimazole (both from Sigma Chemical Co., St Louis, MO, USA), given in freely available drinking water for 7 days. Another ten mice per group served as controls. Mice were weighed and killed, and samples were collected as described above. Thyroids were fixed in $4 \%$ paraformaldehyde in $\mathrm{PBS}$ at $\mathrm{pH} 7.2$ overnight for embedding in paraffin by standard procedures. In a separate experiment, six wild-type and six 8-weekold male transgenic mice were caged individually and treated with equal amounts of goitrogen-containing drinking water. After 1 week, water consumption was determined by weighing the remaining amount of water.

\section{Cell proliferation}

For cell proliferation experiments, eight (four wildtype and four transgenic) 55-day-old male mice were killed and their thyroids were dissected and washed three times in sterile Dulbecco's minimal essential medium (DMEM/F12) containing penicillin, streptomycin and fungizone (Gibco Life Sciences, Burlington, Ontario, Canada). Thyroids of mice from the same group were pooled and digested with $5 \mathrm{ml}$ DMEM containing $1 \mathrm{mg} / \mathrm{ml}$ collagenase (Sigma Chemical Co.) for $30 \mathrm{~min}$ at $37^{\circ} \mathrm{C}$ with shaking and pipetting up and down several times. Follicles were then allowed to settle for 2-3 min, after which they were transferred into fresh DMEM. This washing procedure was repeated twice. The follicle suspensions were aliquoted by volume into 24-well Multiwell tissue culture plate (Becton Dickinson \& Co. Lincoln Park, NJ, USA) to a density of 200-300 follicles per well. Follicles were then cultured for $48 \mathrm{~h}$ in $300 \mu \mathrm{l}$ DMEM at $37^{\circ} \mathrm{C}$ in an atmosphere of $95 \%$ air and $5 \% \mathrm{CO}_{2}$, with the addition of various concentrations of human recombinant IGF-I (Upstate Biotechnology Inc., Lake Placid, NY, USA) or porcine TSH (Sigma Chemical Co.). Four hours before the end of the incubation, $\left.30 \mu \mathrm{l}{ }^{3} \mathrm{H}\right]$ thymidine (NEN, Boston, MA, USA) were added to a final activity of $5 \mu \mathrm{Ci} / \mathrm{ml}$. At the end of the treatment, follicles were adherent to the plastic surface. After the treatment, follicles were counted, washed with $200 \mu \mathrm{l} \mathrm{PBS}$ and eluted with $200 \mu \mathrm{l}$ $0.1 \mathrm{~mol} / \mathrm{l} \mathrm{NaOH}$. DNA was precipitated with $200 \mu \mathrm{l}$ $20 \%$ trichloroacetic acid and washed twice with $400 \mu \mathrm{l}$ cold $75 \%$ ethanol. Radioactivity was determined using Universol liquid scintillation solution (ICN Biochemicals Inc., Irvine, CA, USA) in a Wallac 1450 Microbeta liquid scintillation counter (Wallac, Turku, Finland). This experiment was repeated three times. 


\section{RIAs}

Tri-iodothyronine $\left(\mathrm{T}_{3}\right)$ and thyroxine $\left(\mathrm{T}_{4}\right)$ levels were measured using Coat-a-Count Total $\mathrm{T}_{3}$ and Total $\mathrm{T}_{4}$ kits (Diagnostic Products Corporation, Los Angeles, CA, USA), according to the manufacturer's instructions. Serum TSH was measured using the Biotrak, rat TSH- $\left[{ }^{125} \mathrm{I}\right]$ assay system with magnetic separation (Amersham Life Sciences, Amersham, Bucks, UK). Serum thyroid hormone-binding capacity was measured using a Coat-a-Count $\mathrm{T}_{3}$ uptake kit (Diagnostic Products) based on the competition in radioactive $\mathrm{T}_{3}$ uptake between $\mathrm{T}_{3}$-specific antibody and unoccupied thyroid hormone-binding sites in the sample serum.

\section{Image analysis}

Hematoxylin and eosin stained thyroid sections were photographed at $\times 100$ magnification. Micrographs were scanned using an Abaton Scan 300/Color scanner (Freemont, CA, USA) at 100 pixels per inch and 16-level gray scale. Digitized images were analyzed on a PC computer using the UTHSCSA ImageTool program (developed at the University of Texas Health Science Center at San Antonio, TX, USA). Total area of the thyroid section, areas of the thyroid follicles and the number of follicles were determined in untreated animals. From these data, average follicular area and the number of follicles per square millimeter were calculated. Using the same program, images from goitrogen-treated animals were analyzed for the number of cell nuclei per unit area. Four areas of the sections were randomly chosen and the numbers of cell nuclei were automatically determined by density.

\section{Immunohistochemistry}

Paraffin sections of thyroid tissues ( $5 \mu \mathrm{m}$ thick) were deparaffinized and rehydrated. Sections were then treated with $20 \mu \mathrm{g} / \mathrm{ml}$ proteinase $\mathrm{K}$ for $15 \mathrm{~min}$, then with 3\% hydrogen peroxide for $5 \mathrm{~min}$ and blocked with $1 \%$ normal horse serum for $20 \mathrm{~min}$. Sections were incubated with a 1:1000 dilution of rabbit anti-rat IGFBP-1 antiserum (kindly provided by Dr M Lewitt, University of Sydney, Australia) or with $10 \mu \mathrm{g} / \mathrm{ml} \mathrm{rabbit}$ anti-human IGF-I antiserum that cross-reacts with mouse IGF-I (GroPep, Adelaide, Australia), each in 1\% normal horse serum. Antigen-antibody complexes were detected using biotinylated horse anti-rabbit IgG (Vectastain Universal Elite ABC Kit, Vector Labs, Burlingame, CA, USA) with 3,3'-diaminobenzidine (Sigma Chemical Co.) as a substrate. The sections were photographed at $\times 400$ magnification.

\section{Statistical analysis}

Numerical data were analyzed using PC-SAS (22), unless stated otherwise. In the age study, Pearson correlation coefficients (PCCs) between age, type, treatment, mouse weight, RTW, TSH, $\mathrm{T}_{3}$ and $\mathrm{T}_{4}$ were determined. Least-squares ANOVA was performed using the general linear models analysis. The mathematical model included age, treatment and interaction between the two. There were five animals per group in a $3 \times 2$ design (three ages, two types; $n=30$ ). There was one sample and one observation per animal for each parameter for RTW, TSH, $\mathrm{T}_{3}$ and $\mathrm{T}_{4}$. In the goitrogen study, there were ten animals per group in a $2 \times 2$ design (transgenic vs wild-type and treated vs untreated animals; $n=40$ ). The mathematical model included type, treatment and interaction between the two and the statistical analysis was similar to that in the ageeffect study. The effects of TSH and IGF-I on the in vitro DNA synthesis were also analyzed by ANOVA. The values for average follicular area $(n=10)$ were compared between the transgenic and wild-type mice using a two-sample Student's $t$-test. The same test was used to compare goitrogen-containing water consumption $(n=12), \mathrm{T}_{3}$ uptake and thyroid epithelial cell density between wild-type and transgenic mice in goitrogentreated animals. All data are presented as the mean \pm S.E.M.

\section{Results}

\section{Age-related observation}

The changes in body weight, thyroid weight and TSH levels for both wild-type and transgenic mice over the study period are shown in Fig. 1. As previously reported, there was an overall difference in body weight between wild-type and transgenic mice $(P<0.001)$. Thyroid weight was significantly greater in transgenic than wild-type mice on days 25 and 55 $(P<0.05$ and $P<0.01$ respectively) but not on day 15 , with no significant change in serum TSH levels $(P>0.5)$.

\section{Goitrogen treatment}

Goitrogen solution consumption in wild-type and transgenic mice was $39.78 \mathrm{~g}$ and $40.76 \mathrm{~g}(P>0.28)$ per mouse per week respectively or, expressed relative to body weight, $1.18 \mathrm{~g} / \mathrm{g}$ body weight and $1.38 \mathrm{~g} / \mathrm{g}$ body weight $(P>0.27)$ respectively. Differences in the RTW and serum TSH, $\mathrm{T}_{3}$ and $\mathrm{T}_{4}$ concentrations in untreated 55-day-old wild-type and transgenic mice are shown in Fig. 2. RTW was significantly higher in transgenic mice $(P<0.001)$, whereas serum $\mathrm{T}_{3}$ and $\mathrm{T}_{4}$ were significantly lower in transgenic mice, compared with wild-type mice $(P<0.03$ and $P<0.007$ respectively). Serum TSH levels were similar in wild-type and transgenic mice. In both wild-type and transgenic mice, goitrogen treatment significantly increased RTW $(P<0.005)$ and TSH levels $(P<0.0005)$, amid decreased $\mathrm{T}_{3}$ and $\mathrm{T}_{4}$ levels $(P<0.005$ and $P<0.0005$ 

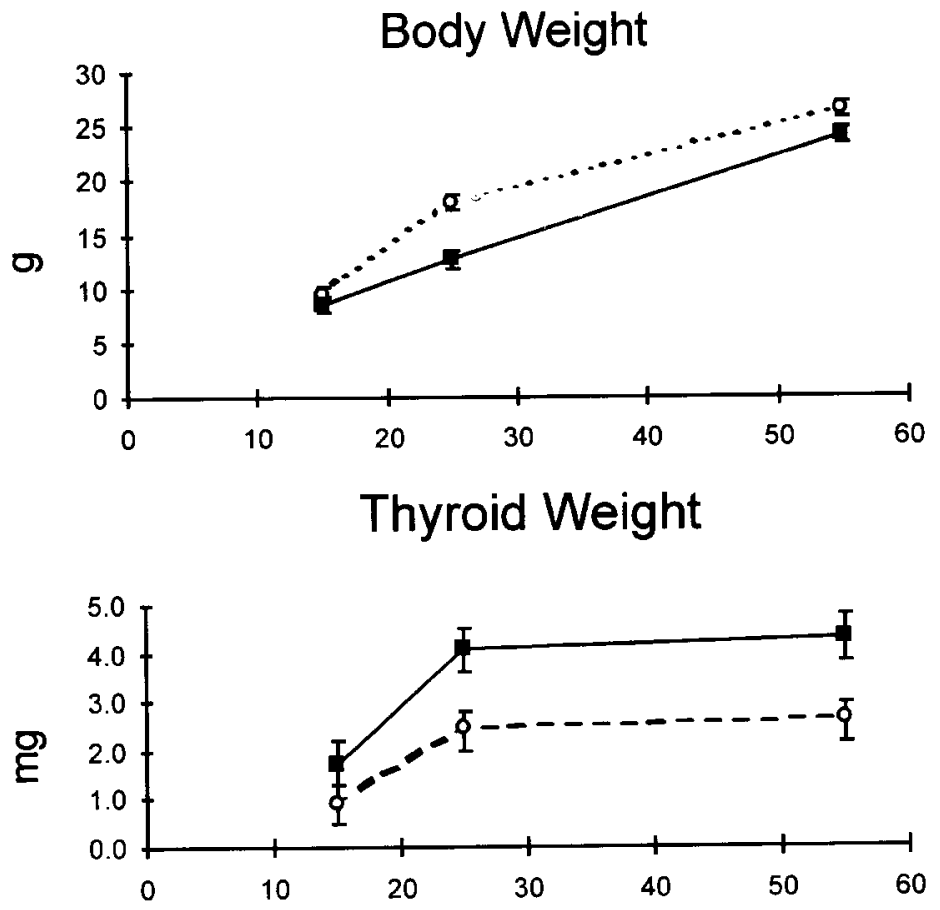

TSH

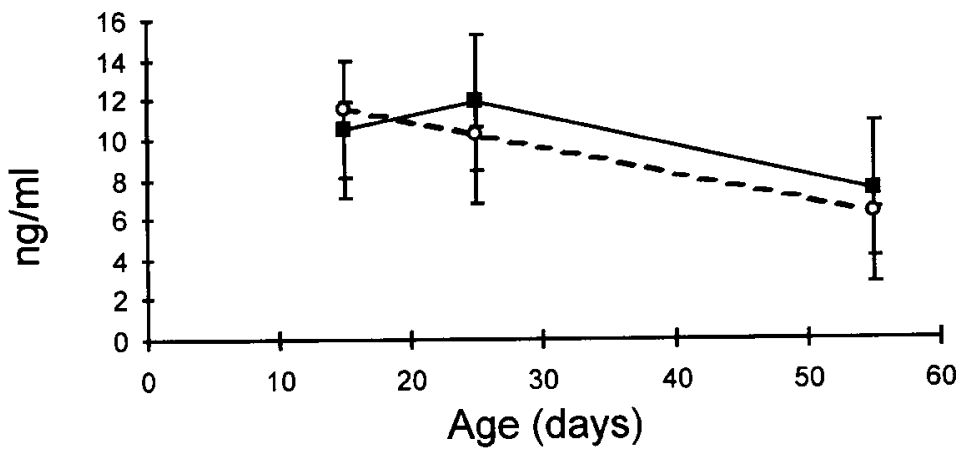

Figure 1 Changes with age in body weight, thyroid weight and TSH levels in wild-type $(O)$ and transgenic $(\boldsymbol{\square})$ mice. The upper panel shows the body weight at the ages of 15,25 and 55 days (means \pm S.E.M., $n=30$, overall $P=0.0001$, determined by two-way ANOVA). The middle panel shows the changes in thyroid weight between wild-type and transgenic mice, which was significant $(P=0.0003)$. The lower panel depicts the changes in TSH with age in wild-type and transgenic mice. There was no significant difference in TSH levels between the two groups of mice. respectively). Serum TSH concentrations in goitrogentreated transgenic mice were significantly higher than in wild-type mice $(P<0.015)$. RTW, serum $\mathrm{T}_{3}$ or $\mathrm{T}_{4}$ in goitrogen-treated transgenic mice were not significantly different from those of wild-type mice. The percent increase of RTW due to goitrogen treatment was less pronounced in transgenic when compared with wildtype mice $(P<0.05)$, while the percent increase in serum TSH levels was more marked in transgenic mice compared with wild-type mice $(P<0.05)$.

Photomicrographs of thyroid glands from untreated and goitrogen-treated 55-day-old wild-type and transgenic mice are shown in Fig. 3. Average follicular area and follicular density were similar for both groups of mice; 2394 vs $2446 \mu \mathrm{m}^{2}$ and 167 vs 182 follicles per $\mathrm{mm}^{2}$ respectively. Goitrogen treatment resulted in a microfollicular pattern in both wild-type and transgenic mice. In goitrogen-treated mice, there was an average of 5553 (wild-type) vs 5325 (transgenic) nuclei $/ \mathrm{mm}^{2}$ of thyroid section with no significant difference $(P>0.48)$ between the wild-type and transgenic mice.

Representative photomicrographs of immunohistochemically stained thyroid sections are presented in Fig. 4. Cytoplasm of transgenic follicular cells was stained more intensely than that of wild-type when incubated with anti-human IGF-I antiserum and considerably more intensely when incubated with anti-rat IGFBP-1 antiserum.

In goitrogen-treated mice, a significant negative correlation was observed between serum $\mathrm{T}_{3}$ and TSH concentrations $(P<0.015$ and $P<0.02$ for wild-type and transgenic mice respectively, Fig. 5). However, 


\section{RTW}

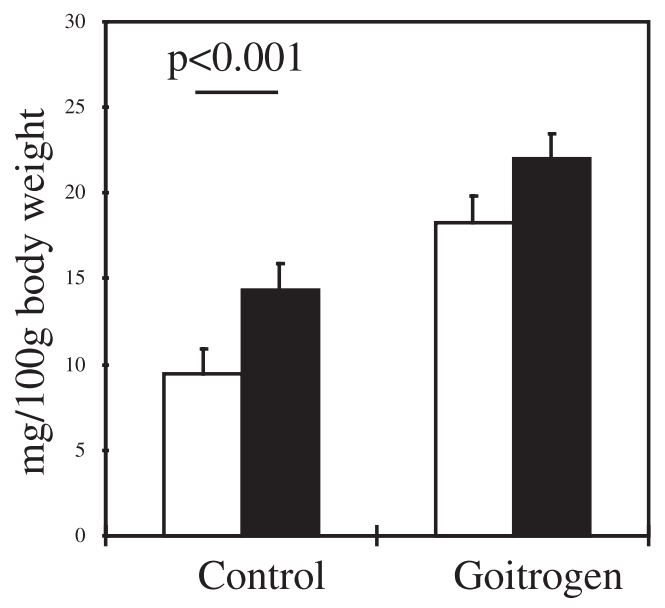

Serum T3

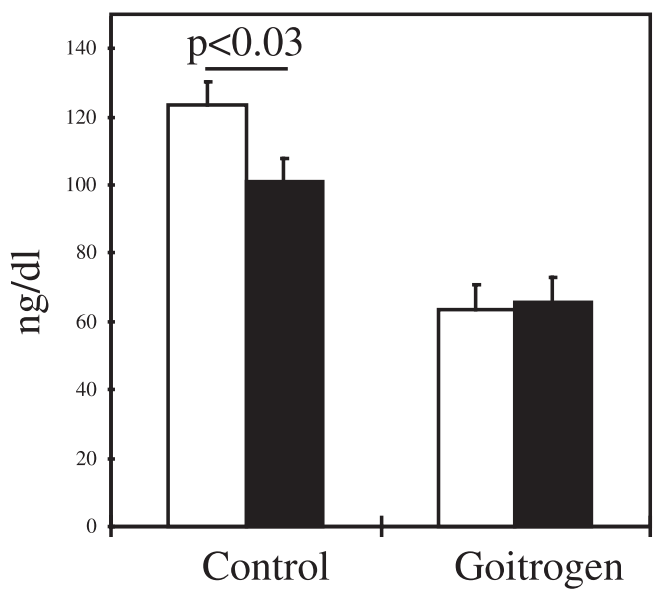

Serum TSH

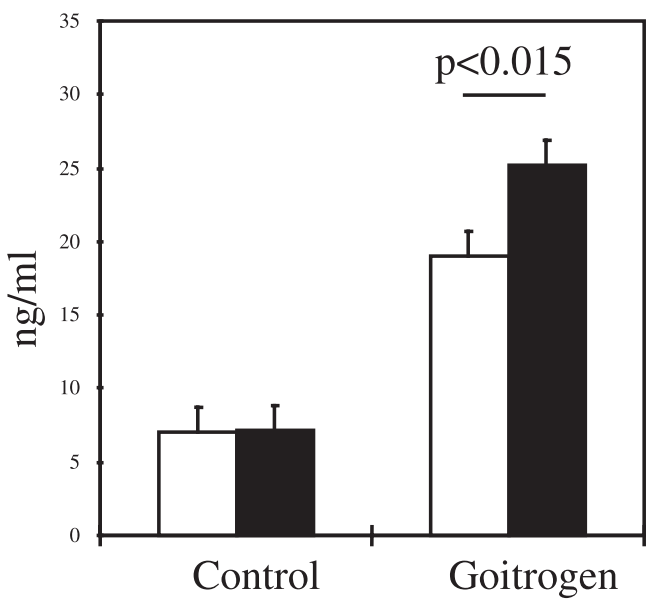

Serum T4

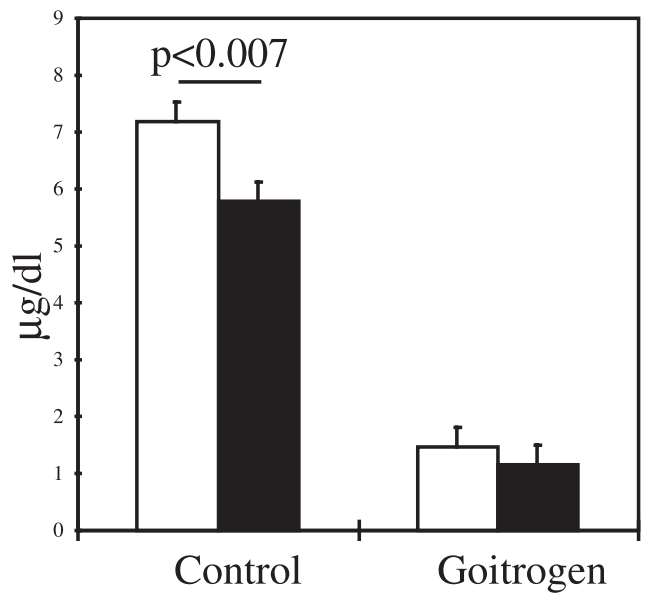

Figure 2 Comparison of RTW and TSH, $\mathrm{T}_{3}$ and $\mathrm{T}_{4}$ levels in wild-type (open bars) and transgenic (filled bars) mice, untreated or treated with $0.5 \%$ sodium perchlorate and $0.05 \%$ methimazole, given in freely available drinking water for 7 days. The data are the mean \pm s.E.M. for $n=10$ mice in each group (means \pm S.E.M., $n=40$, overall $P<0.0001$, for each of RTW, $\mathrm{TSH}_{3} \mathrm{~T}_{3}$ and $\mathrm{T}_{4}$, determined by two-way ANOVA).

the slope of the line of best fit was less steep in wild-type $(\mathrm{y}=102.0-2.02 \mathrm{x})$ than transgenic $(\mathrm{y}=85.6-0.87 \mathrm{x})$, indicating that lower concentrations of $\mathrm{T}_{3}$ were required to suppress pituitary TSH secretion in transgenic compared with the wild-type mice.

\section{Thyroid hormone-binding capacity}

To examine whether the differences in serum concentrations of total $\mathrm{T}_{3}$ and $\mathrm{T}_{4}$ may have resulted from differences in thyroid hormone-binding proteins, we used a $\mathrm{T}_{3}$ uptake test to measure serum binding capacity for thyroid hormones. $\mathrm{T}_{3}$ uptake was significantly elevated by $9 \%(P<0.0002)$ in transgenic vs wild-type mice, indicating a lower availability of unoccupied thyroid hormone-binding sites in the serum of transgenic mice (Fig. 6). Based on percent uptake and total $\mathrm{T}_{3}$ and $\mathrm{T}_{4}$ values, the free $\mathrm{T}_{3}$ index $\left(\mathrm{FT}_{3} \mathrm{I}\right)$ and free $\mathrm{T}_{4}$ index $\left(\mathrm{FT}_{4} \mathrm{I}\right)$ were calculated. $\mathrm{FT}_{3} \mathrm{I}$ was 59.4 and $53.1 \mathrm{ng} / \mathrm{ml}$ for wild-type and transgenic mice respectively, while $\mathrm{FT}_{4} \mathrm{I}$ for the wild-type and transgenic mice was 3.5 and $3.0 \mu \mathrm{g} / \mathrm{ml}$ respectively. This amounts to a $11 \%(P<0.01)$ and $14 \%(P<0.005)$ reduction in transgenic compared with wild-type mice, with respect to $\mathrm{FT}_{3} \mathrm{I}$ and $\mathrm{FT}_{4} \mathrm{I}$.

\section{In vitro experiments}

The effects of in vitro treatment of isolated thyroid follicles with porcine TSH and human recombinant IGF-I on $\left[{ }^{3} \mathrm{H}\right]$ thymidine incorporation are presented in Fig. 7. When the entire dose-response curve was 

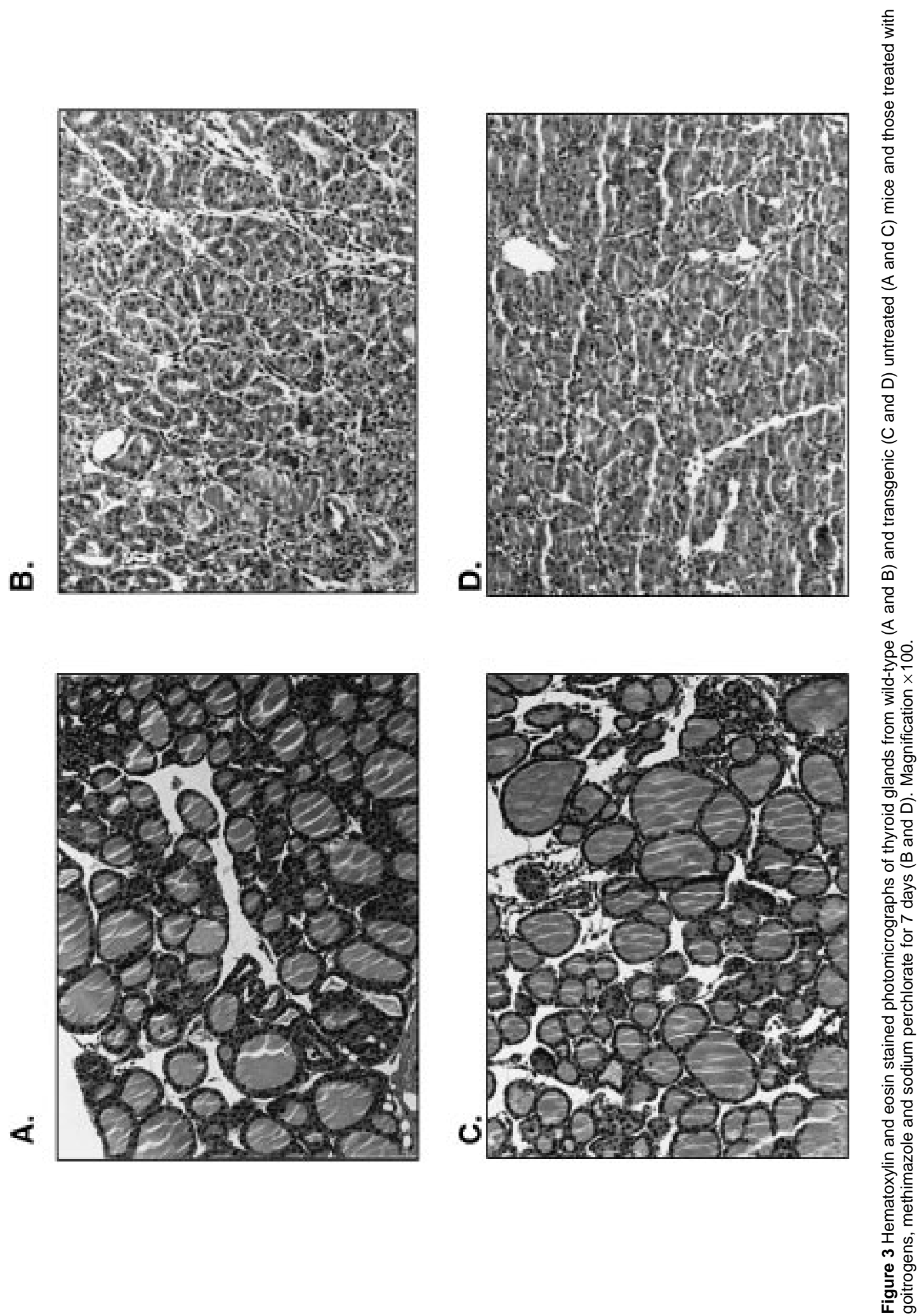

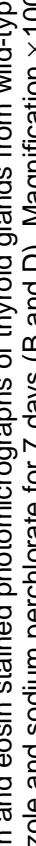



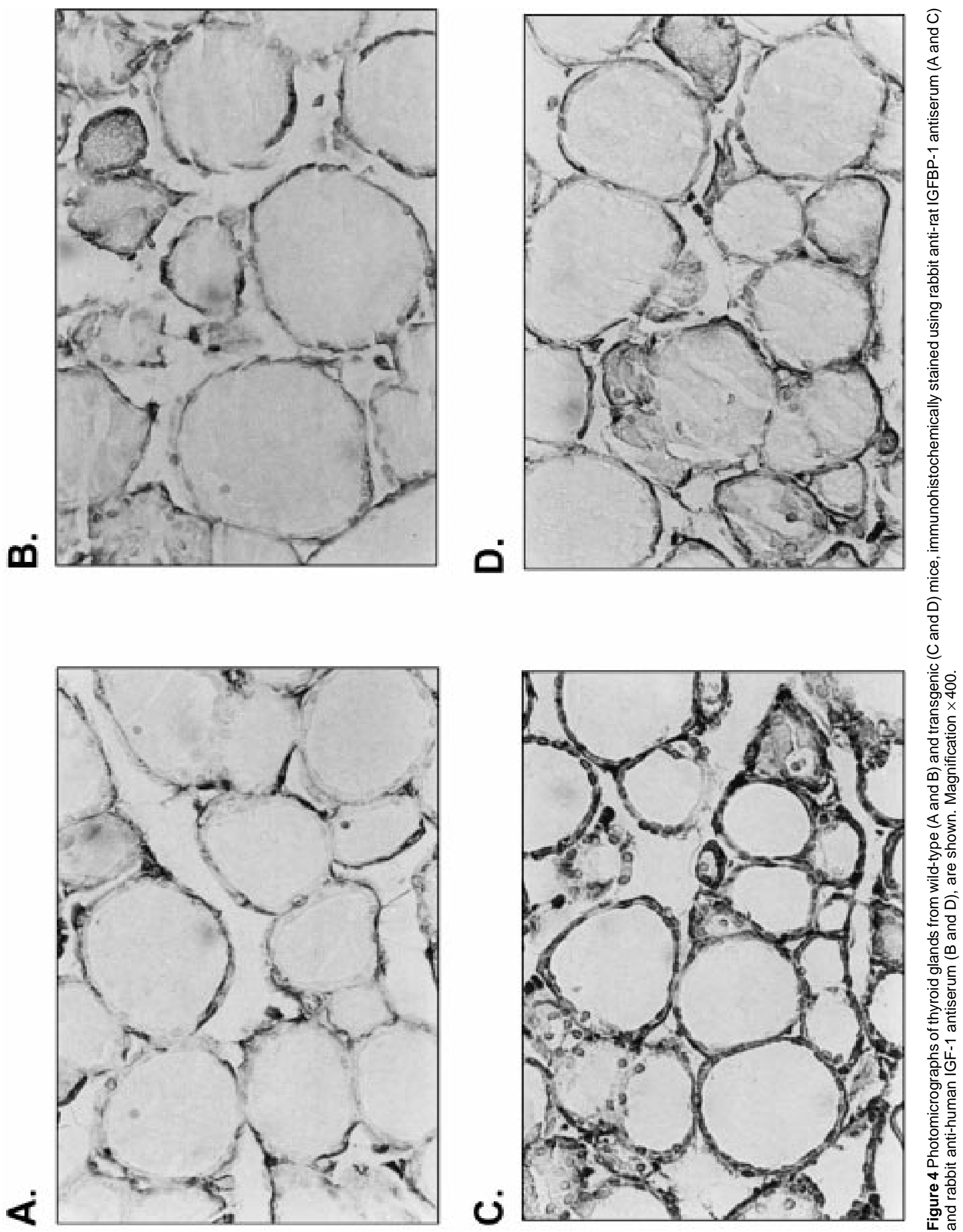


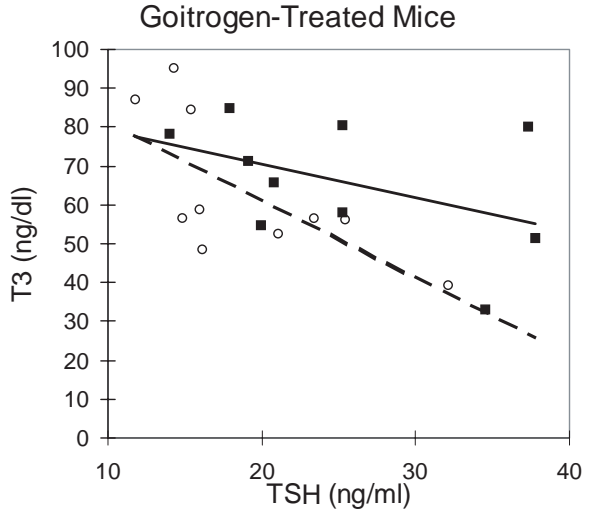

Figure 5 The relationship between serum $\mathrm{T}_{3}$ and TSH concentrations in 55-day-old goitrogen-treated mice. PCC in wild-type $(O=-0.77, P<0.015$; and in transgenic $(\square)$ mice $P C C=-0.90, P<0.02$. Lines of the best fit for wild-type (dotted line; $y=102.0-2.02 x$ ) and for transgenic (continuous line $y=85.6$ $0.87 x$ ) are included.

considered, wild-type mice exhibited higher DNA synthesis than transgenic mice. There was an overall difference between wild-type and transgenic mice in terms of thyroid follicular responsiveness to IGF-I ( $n=12$ for each dose and type, $P<0.02$, by ANOVA). When individual concentrations were evaluated, significant differences between wild-type and transgenic mice were observed in follicles treated with 3 and $10 \mathrm{nmol} / \mathrm{l}$ IGF-I $(P<0.005$ and $P<0.002$ respectively). There was no statistical difference $(P>0.39)$ in response to TSH between follicles from wild-type and transgenic mice in terms of their DNA synthesis.

\section{Discussion}

While transgenic mice have been shown to be smaller than wild-type, the relative size of most organs is similar in transgenic and wild-type (17). Thus, the finding that the RTW was significantly larger in transgenic mice was unexpected. The difference in thyroid weight between transgenic and wild-type mice was apparent as early as 15 days of age, but was more marked after weaning at 25 days of age. These differences can be ascribed to the expression of the transgene in the thyroid follicular cells from these mice, based on immunohistochemical data. As a result of the transgenic IGFBP-1 overexpression, there was an increased staining intensity of IGF-I in thyroid follicular cells, presumably bound to IGFBP-1 and thus made less available to interact with the IGF-1 receptors (23).

Histological analysis indicated that there was no significant difference in number of follicles per unit area between transgenic and wild-type mice, despite a difference in the thyroid size. This implies a larger number of thyroid follicles in transgenic mice. Even at the earliest time-point studied, 15 days of age, there was no significant difference in TSH levels between
T3 Uptake

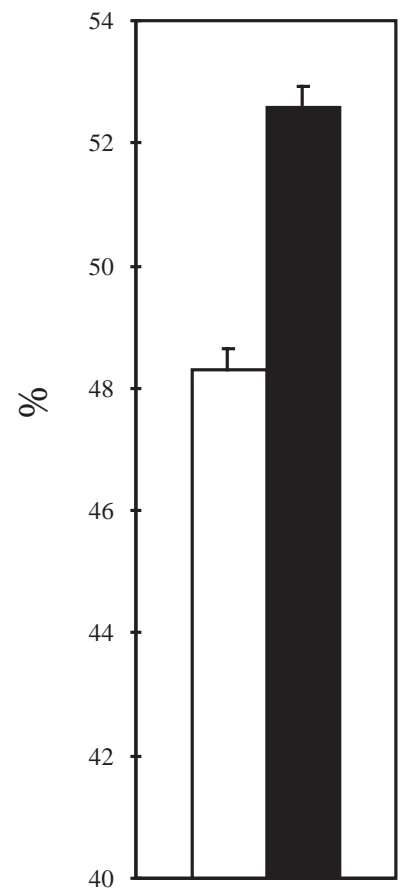

Figure 6 Serum thyroid hormone-binding capacity in wild-type (open bars) and transgenic (filled bars) mice. The percent uptake of radiolabeled $\mathrm{T}_{3}$ by anti- $\mathrm{T}_{3}$ antibody-coated tubes was measured in the presence of serum from seven mice from each group. The data are the mean \pm S.E.M. $(P<0.0002)$.

transgenic and wild-type mice. We have previously shown that the IGFBP-1 transgene is expressed as early as the blastocyst stage during embryogenesis (24). It is possible that TSH may have been elevated earlier during development, resulting in the observed increase in RTW in the transgenic mice. The results of our study indicate that thyroid weight increased 2- to 3-fold in both wild-type and transgenic mice between 15 and 25 days of age, without any accompanying increase in serum TSH levels. This suggests that thyroid growth during this time-period may be less dependent on TSH than at other stages of development.

IGF-I has been demonstrated to enhance thyroid cell proliferation (14). Besides attenuation of IGF function, under certain in vitro conditions, exogenous addition of IGFBP-1 has been shown to enhance IGF-I action in cultured cells, possibly by increasing IGF-I availability at the cell surface (25). This effect appears to depend upon the phosphorylation state of the IGFBP-1, with the more highly phosphorylated IGFBP-1 having a higher affinity for IGF and being more inhibitory (26). Circulating IGFBP-1 in these transgenic mice is highly phosphorylated (D R Clemmons, University of North Carolina, Chapel Hill, USA personal communication). While the phosphorylation status of the locally 
Thymidine Incorporation in Isolated Thyroid Follicles

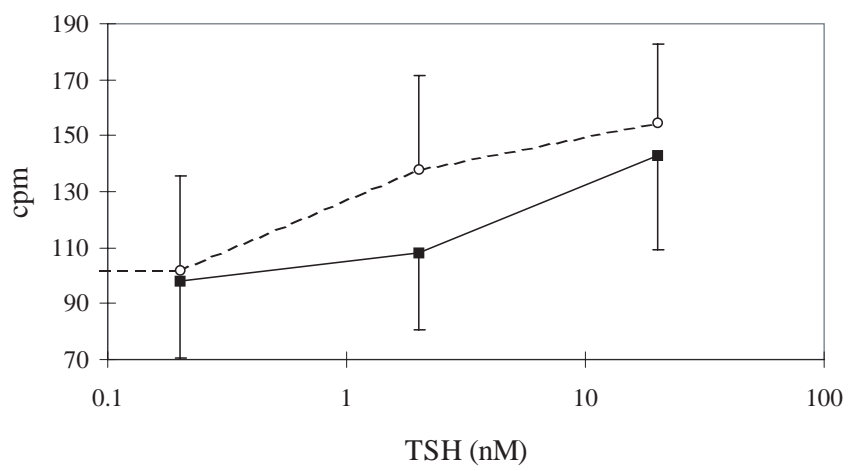

Figure 7 The effects of TSH and IGF-I on $\left[{ }^{3} \mathrm{H}\right]$ thymidine incorporation into DNA in isolated thyroid follicles from wild-type $(\bigcirc)$ and transgenic $(\square)$ mice. The statistical significance for the difference between dose-response curves obtained with follicles from wild-type and transgenic mice was $P>0.39$ and $P<0.01$ for TSH and IGF-I respectively, as determined by two-way ANOVA.

expressed IGFBP-1 in the thyroid gland of the transgenic mice is not known, the in vitro studies with isolated thyroid follicles from transgenic mice demonstrated a decreased response in DNA synthesis to IGF-I, as compared with follicles from wild-type mice. Therefore, the increased size of the thyroid gland in transgenic animals may not be due to the enhancing effect of IGFBP-1 action on IGF-I.

Since the thyroid glands were not smaller in transgenic compared with wild-type mice, other autocrine/ paracrine growth factors present in vivo (27) may have compensated for the reduced action of IGF-I observed in vitro. Insulin, whose fasting serum levels are significantly elevated in the transgenic mice (18), would be a candidate for stimulation of follicular cell DNA synthesis (28). Other potentially compensating factors are epidermal growth factor $(\mathrm{EGF})(2,3)$ and fibroblast growth factor $(29,30)$. It has been demonstrated by using porcine thyroid follicles cultured on extracellular matrix that EGF stimulates new follicle formation, whereas IGF-I and TSH increase DNA synthesis within the follicles, without stimulating the development of new follicles (3). It is not known whether perturbation of the IGF-I system by overexpression of IGFBP-1 is compensated for by expression of other autocrine/ paracrine growth factors such as EGF, which may enhance the growth of the thyroid gland.

Goitrogen treatment resulted in a microfollicular

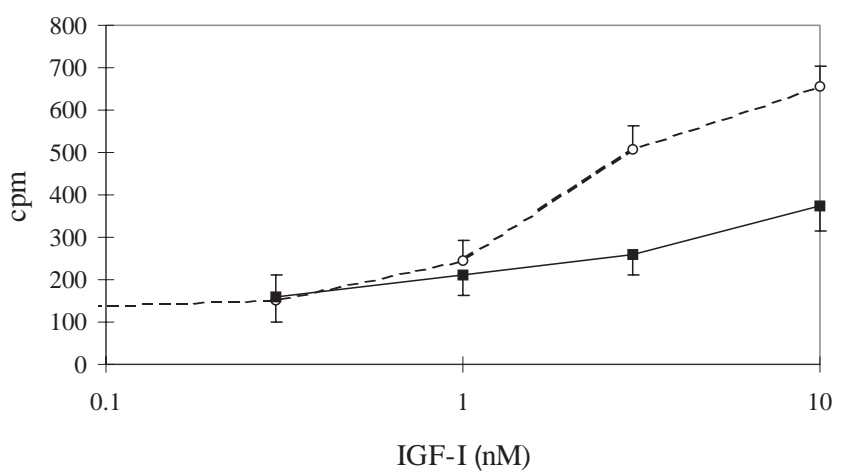

goiter, characteristic of iodine deficiency (31). However, the relative increase in RTW following goitrogen treatment compared with the untreated group was less pronounced in transgenic mice than in wild-type mice, despite the difference in TSH levels. This supports the concept that IGF-I is involved in TSH-mediated growth $(3,32)$ and that the overexpression of IGFBP-1 in transgenic mice impairs TSH action $(27,33)$.

Serum levels of $\mathrm{T}_{3}$ and $\mathrm{T}_{4}$ were decreased in transgenic, compared with wild-type mice. The lower $\mathrm{T}_{3}$ and $\mathrm{T}_{4}$ levels could be partially accounted for by the reduction in thyroid hormone-binding capacity of serum from transgenic mice. Since no validated assay of free $\mathrm{T}_{3}$ or $\mathrm{T}_{4}$ is available for use in mouse serum, it was not possible to determine the concentrations of free hormones. However, $\mathrm{FT}_{3} \mathrm{I}$ and $\mathrm{FT}_{4} \mathrm{I}$ were significantly different between the untreated wild-type and transgenic mice, although the differences in $\mathrm{FT}_{3} \mathrm{I}$ and $\mathrm{FT}_{4} \mathrm{I}$ were somewhat less pronounced than the differences in $\mathrm{T}_{3}$ and $\mathrm{T}_{4}$.

The hypothalamo-pituitary-thyroid feedback mechanism may not be identical in transgenic and wild-type mice. Although serum TSH levels increased an expected 2- to 3-fold in both goitrogen-treated wild-type and transgenic mice, TSH levels were not different between untreated wild-type and transgenic mice. However, serum TSH levels were elevated in goitrogen-treated transgenic mice compared with wild-type, with no 
differences in $\mathrm{T}_{3}$ or $\mathrm{T}_{4}$ levels. This may indicate that higher TSH levels are required to stimulate the same degree of thyroid hormonogenesis in mice, that is the transgenic thyroids were less responsive to TSH than those from wild-type mice. We came to a similar conclusion when TSH levels were plotted against a broad range of $\mathrm{T}_{3}$ concentrations, since the regression lines for goitrogen-treated transgenic and wild-type mice had different slopes. The decreased slope in transgenic mice suggests that there may be an impaired response of thyroid follicle cells to TSH, with regard to thyroid hormone synthesis. This is consistent with previous reports that IGF-I plays a facilitatory role in TSHinduced thyroid hormone synthesis $(3,32)$.

The in vitro studies indicate that IGFBP-1 expression in transgenic mice attenuates follicular DNA synthesis in response to IGF-I. Normal growth and development of the thyroid gland are regulated by cytokines and growth factors, including IGF-I (34). This attenuation of IGF-I response in transgenic follicles can be explained by the general inhibitory effect of IGFBP-1 on the growth stimulation by IGF-I (17). Physiologically, IGFBPs may have a role in the thyroid growth autoregulatory loop, since IGFBP mRNAs and proteins are down-regulated by $\operatorname{TSH}(27,33)$, while $\mathrm{T}_{4}$ treatment increases serum IGFBP-1, -2 and -4 levels in hypophysectomized fetal pigs (35). Similarly, serum IGFBP-1 increases after thyroid hormone replacement in athyrotic patients $(9,12)$.

The in vitro effect of TSH on DNA synthesis in isolated follicles from both wild-type and transgenic mice was smaller in comparison with the effect observed with IGF-I. Growth of human or porcine thyroid follicles on a flat surface was found not to be stimulated by TSH to a great extent (36). Although the mean level of radiolabeled thymidine incorporation in isolated follicles in response to TSH was lower in transgenic compared with wild-type mice, this difference failed to achieve statistical significance. Previous studies have indicated the requirement of insulin or IGF-I in the culture medium to obtain maximal effects of TSH on DNA synthesis (34) and the effect of TSH on thyroid cell proliferation is thought to be partially mediated by IGF-I (37). The lack of difference in mitogenic response to TSH between wild-type and transgenic mice may be due to different signaling pathways used by TSH and IGF-I. While TSH predominantly utilizes cAMP as a second messenger $(37,38)$ and its effect can be mimicked by the addition of N6-2'-O-dibutyryladenosine cAMP (32), IGF-I receptor exhibits protein tyrosine kinase C activity $(39,40)$. Moreover, each pathway seems to be responsible for inducing different immediate early gene expression in rat thyrocytes (41).

In the future, similar experiments with transgenic mice expressing other IGFBPs should be conducted, to determine any inter-relationship of IGFBP-1 and other IGFBPs and whether the observed effects are direct or via attenuation of IGF action.
The data reported in this paper indicate that the IGF system is important for thyroid function and growth, and that partial inhibition of IGF-I action can be compensated for by thyroid enlargement, despite an elevated expression of IGFBP-1.

\section{Acknowledgements}

This research was supported by grants from the Medical Research Council of Canada and from the $\mathrm{H} \mathrm{E}$ Sellers Fund. L J M is a recipient of an endowed Research Professorship in Metabolic diseases.

\section{References}

1 Phillips ID, Becks GP, Logan A, Wang JF, Smith C \& Hill DJ. Altered expression of insulin-like growth factor-I (IGF-I) and IGF binding proteins during rat thyroid hyperplasia and involution. Growth Factors 199410 207-222.

2 Van der Laan BF, Freeman JL \& Asa SL. Expression of growth factors and growth factor receptors in normal and tumorous human thyroid tissues. Thyroid 1995 5 67-73.

3 Bechtner G, Schopohl D, Rafferzeder M, Gärtner R \& Welsch U. Stimulation of thyroid cell proliferation by epidermal growth factor is different from cell growth induced by thyrotropin or insulin-like growth factor I. European Journal of Endocrinology $1996134639-648$.

4 Nakahashi K, Kitahori Y, Konishi N, Ohnishi T, Sugimura M \& Hiasa Y. Establishment of a rat thyroid carcinoma cell line in vitro demonstrating high DNA synthesis in response to insulin-like growth factor I. Cancer Letters $1996101247-255$.

5 Saji M, Akamizu T, Sanchez M, Obici S, Avvedimento E, Gottesman ME et al. Regulation of thyrotropin receptor gene expression in rat FRTL-5 thyroid cells. Endocrinology 1992130 520-533.

6 Hsiao PJ \& Tsai JH. Increased insulin-like growth factor-1 receptors in thyroid tissues of Graves' disease. Journal of the Formosan Medical Association 199493 925-932.

7 Maiorano E, Ambrosi A, Giorgino R, Fersini M, Pollice L \& Ciampolillo A. Insulin-like growth factor 1 (IGF-1) in multinodular goiters: a possible pathogenetic factor. Pathology Research and Practice $19941901012-1016$.

8 Dawson TP, Radulescu A \& Wynford-Thomas D. Expression of mutant p2 $1^{\text {ras }}$ induces insulin-like growth factor 1 secretion in thyroid epithelial cells. Cancer Research 199555 915-920.

9 Angervo M, Toivonen J, Leinonen P, Valimaki M \& Seppala M. Thyroxine withdrawal is accompanied by decreased circulating levels of insulin-like growth factor-binding protein-1 in thyroidectomized patients. Journal of Clinical Endocrinology and Metabolism 199376 1199-1201.

10 Tada H. Watanabe Y, Futakuchi Y \& Amino N. Change in serum concentration of insulin-like growth factor II (IGF-II) in patients with thyroid disease. Endocrine Journal 199441 $541-545$.

11 Thomas MR, Miell JP, Taylor AM, Ross RJ, Arnao JR, Jewitt DE et al. Endocrine and cardiac paracrine actions of insulin-like growth factor-I (IGF-I) during thyroid dysfunction in the rat: is IGF-I implicated in the mechanism of heart weight/body weight change during abnormal thyroid function? Journal of Molecular Endocrinology $199310313-323$.

12 Rodriguez-Arnao J, Miell J, Thomas M, McGregor AM \& Ross RJ. Changes in hepatic insulin-like growth factor-binding proteins -1 , -2 and -3 mRNA levels in rats with altered thyroid status. Journal of Endocrinology $1994140251-255$.

13 Rotwein P, Bichell DP \& Kikuchi K. Multifactorial regulation of IGF-I gene expression. Molecular Reproduction and Development $199335358-363$. 
14 Akiguchi I, Strauss K, Borges M, Silva JE \& Moses AC. Thyroid hormone receptors and 3,5,3'-triiodothyronine biological effects in FRTL5 thyroid follicular cells. Endocrinology 1992131 1279-1287.

15 Hussain MA, Schmitz O, Jorgensen JO, Christiansen JS, Weeke J, Schmid et al. Insulin-like growth factor I alters peripheral thyroid hormone metabolism in humans: comparison with growth hormone. European Journal of Endocrinology 1996 134 563-567.

16 D'Ercole AJ, Ye P \& Gutierrez-Ospina G. Use of transgenic mice for understanding the physiology of insulin-like growth factors. Hormone Research 199645 (Suppl 1) 5-7.

17 Rajkumar K, Barron D, Lewitt MS \& Murphy LJ. Growth retardation and hyperglycemia in insulin-like growth factor binding protein-1 transgenic mice. Endocrinology 1995136 4029-4034.

18 Rajkumar K, Dheen T, Krsek M \& Murphy LJ. Impaired estrogen action in the uterus of insulin-like growth factor binding protein1 transgenic mice. Endocrinology 1996137 1258-1264.

19 Liu YY, Rajkumar K \& Murphy LJ. Hepatic regeneration in insulinlike growth factor binding protein-1 transgenic mice. Hepatology $199930674-680$.

20 McBurney MW, Staines WA, Boekelheide K, Parry D, Jardine K \& Pickavance L. Murine PGK-1 promoter drives widespread but not uniform expression in transgenic mice. Developmental Dynamics $1994200278-293$.

21 Farnararo M, Sgaragli G, Bigazzi M \& Melani F. Levels of enzymes involved in glycolysis, gluconeogenesis, glycogenesis and hexose monophosphate shunt in rat thyroid. Life Sciences $19687667-672$.

22 SAS. SAS/STAT User's Guide, edn 6.03. Cary, NC: Statistical Analysis System Institute, Inc., 1988.

23 Lee PD, Conover CA \& Powell DR. Regulation and function of insulin-like growth factor-binding protein-1. Proceedings of the Society for Experimental Biology and Medicine 1993204 4-29.

24 Huang H, Rajkumar K \& Murphy LJ. Reduced fecundity in insulinlike growth factor binding protein-1 transgenic mice. Biology of Reproduction 199656 284-290.

25 Elgin RG, Busby WH \& Clemmons DR. An insulin-like growth factor (IGF) binding protein enhances the biological response to IGF-I. Proceedings of the National Academy of Sciences of the USA $1987843254-3258$.

26 Frost RA \& Tseng L. Insulin-like growth factor-binding protein-1 is phosphorylated by cultured human endometrial stromal cells and multiple protein kinases in vitro. Journal of Biological Chemistry $199126618082-18088$.

27 Phillips ID, Becks GP, Wang JF, Han VK \& Hill DJ. Hormonal regulation and biological actions of insulin-like growth factor binding proteins in isolated ovine thyroid follicles. Endocrinology $19941341238-1246$.

28 Vainio M, Saarinen P \& Tornquist K. Insulin stimulates proliferation of rat thyroid FRTL-5 cells. Journal of Cellular Physiology $1997171336-342$.

29 Bechtner G, Potscher C \& Gärtner R. Role of autocrine and paracrine factors in thyroid follicle growth. Thyroidology 19924 $1-5$.
30 Gärtner R, Veitenhansl M, Aktas J \& Schopohl D. Role of basic fibroblast growth factor in the pathogenesis of nodular goiter. Experimental and Clinical Endocrinology and Diabetes 1996104 (Suppl 4) 36-38.

31 Gerber H, Huber G, Peter HJ, Kampf J, Lemarchand-Beraud T, Fragu P et al. Transformation of normal thyroids into colloid goiters in rats and mice by diphenylthiohydantoin. Endocrinology $19941352688-2699$.

32 Becks GP, Buckingham DK, Wang JF, Phillips ID \& Hill DJ. Regulation of thyroid hormone synthesis in cultured ovine thyroid follicles. Endocrinology 1992130 2789-2794.

33 Eggo MC \& Sheppard MC. Autocrine growth factors in the thyroid. Molecular and Cellular Endocrinology 1994100 97-102.

34 Burikhanov R, Coulonval K, Pirson I, Lamy F, Dumont JE \& Roger PP. Thyrotropin via cyclic AMP induces insulin receptor expression and insulin co-stimulation of growth and amplifies insulin and insulin-like growth factor signaling pathways in dog thyroid epithelial cells. Journal of Biological Chemistry 1996271 29400-29406.

35 Latimer AM, Hausman GJ, McCusker RH \& Buonomo FC. The effects of thyroxine on serum and tissue concentrations of insulin-like growth factors (IGF-I and -II) and IGF-binding proteins in the fetal pig. Endocrinology 1993133 1312-1319.

36 Gärtner R. Thyroid growth in vitro. Experimental and Clinical Endocrinology $199210032-35$.

37 Hofbauer LC, Rafferzeder M, Janssen OE \& Gärtner R. Insulin-like growth factor I messenger ribonucleic acid expression in porcine thyroid follicles is regulated by thyrotropin and iodine. European Journal of Endocrinology 1995132 605-610.

38 Yamamoto K, Hirai A, Ban T, Saito J, Tahara K, Terano T et al. Thyrotropin induces G1 cyclin expression and accelerates G1 phase after insulin-like growth factor I stimulation in FRTL-5 cells. Endocrinology 1996137 2036-2042.

39 Takano T, Takada K, Tada H, Nishiyama S \& Amino N. Genistein, a tyrosine kinase inhibitor, blocks the cell cycle progression butnot $\mathrm{Ca}^{2+}$ influx induced by BAY K8644 in FRTL-5 cells. Biochemical and Biophysical Research Communications 1993190 801-807.

40 Takano T, Takada K, Tada H, Nishiyama S \& Amino N. Staurosporine can inhibit the G1-S transition induced by a calcium channel agonist by blocking the pathway independent of phorbol ester-sensitive protein kinase $\mathrm{C}$ in rat thyroid cells (FRTL-5). Endocrine Research 199420 235-245.

41 Tominaga T, Dela-Cruz J, Burrow GN \& Meinkoth JL. Divergent patterns of immediate early gene expression in response to thyroid-stimulating hormone and insulin-like growth factor I in Wistar rat thyrocytes. Endocrinology 1994135 1212-1219.

Received 14 December 1998

Accepted 19 April 1999 